Scientific Journal Warsaw University of Life Sciences - SGGW

Problems of World Agriculture volume 17 (XXXII), number 4, 2017: 326-338

DOI: $10.22630 /$ PRS.2017.17.4.108

Ludwik Wicki $^{1}$, Mykola Orlykovskyi ${ }^{2}$, Lesia Zaburanna ${ }^{3}$

${ }^{1}$ Warsaw University of Life Sciences - SGGW

${ }^{2}$ Gnieźnieńska Szkoła Wyższa Milenium, Zhytomyr National Agroecological University

${ }^{3}$ National University of Life and Environmental Sciences of Ukraine

\title{
Agriculture in Poland and Ukraine - Potential and Dynamics of Changes in Production
}

\begin{abstract}
The article attempts to compare the importance of agriculture and the dynamics of its development in Ukraine and Poland. The most important constraints on the development of Ukrainian agriculture were identified, including the unregulated land market, lack of coherent support programs for agriculture and rural areas, poorly developed infrastructure of the agricultural environment and lack of capital for development. It was found that agriculture in Ukraine is characterized by a high growth rate of productivity and production. The observed output gap in relation to agriculture in Poland is about 10 years. The agricultural sector in Ukraine has about 10\% share in generating GDP and as much as $40 \%$ share in exports. Such high importance can be maintained even in the conditions of economic development, as there are large reserves in the development of agribusiness. The most important development factors include the introduction of a coherent program for the development of the agribusiness sector, including production of goods with high added value and increasing the availability of capital for the development of agriculture. A great opportunity is the development of trade in the conditions of affiliation with the EU.
\end{abstract}

Key words: productivity gap, agriculture efficiency, production factors, agriculture development

JEL Classification: Q00, Q17, O13, P32

\section{Introduction}

In Ukraine, as in most countries of the former Eastern bloc, after the period of economic transformation, the time has come to build new economic structures. Such activities also concerned agriculture. The situation of agriculture in individual countries varied. A strong sector of private, individual farms has been preserved in Poland, and stateowned farms had only about 20 per cent share in land use. In Ukraine, all agriculture functioned in the form of state-owned or co-operative farms. After the period of economic changes, the changes towards the marketization of economic relations in Ukrainian agriculture were much slower than in Poland. However, some developmental analogies can be noticed. Changes in agriculture are taking place there with a delay in relation to the situation in Poland, but they have a similar course. At the same time, Ukrainian agriculture is becoming a major producer of food not only in Europe, but also on a global scale.

Ukraine as one of the largest countries in Europe has a huge potential for the development of agricultural production. A special feature is that in Ukraine there are some of the most fertile soils in the world, and arable land resources are over 32 million ha.

\footnotetext{
${ }^{1} \mathrm{PhD}$, associated professor, Faculty of Economic Sciences WULS - SGGW, ul. Nowoursynowska 166, 02-787 Warszawa, e-mail: ludwik_wicki@sggw.pl, corresponding author; https://orcid.org/0000-0002-7602-8902

${ }^{2} \mathrm{PhD}$, e-mail: agrofam@o2.p1

${ }^{3} \mathrm{PhD}$, professor, e-mail: alesenka2003@ukr.net
} 
After the formation of independent Ukraine, the old economic structures have disintegrated. This was also true for agriculture and led to a strong decline in production, but also to a significant deterioration of the infrastructure in agriculture and its environment. After the transformation, tens of thousands of large farms were established there, but the land was given to several million small owners, who often do not even have machines for production. Strong obstacles in the development of agriculture are still such matters as the unorganized situation on the agricultural land markets, the lack of a stable law with regard to agricultural support, but also a very low level of development of the purchasing, processing and distribution system of agricultural production (Wicki and Orlykovskyi, 2016). The restriction for changes is the obsolete equipment of farms and the shortage of funds for investments (Zaika et al., 2017). It is the limited resources for development that constitute a significant barrier to changes in agriculture and the entire agribusiness in Ukraine. It is still an important sector of the economy with a $10 \%$ share in generating GDP. In Poland, after the transformation, the importance of agriculture and agribusiness in the economy decreased with the increase in the total production value of the sector, but also the share of agricultural processing in the agribusiness structure increased, which required significant investments (Wicka et al., 2016).

The inflow of funds to the agricultural sector in Ukraine is limited for many reasons. The basic one is low domestic demand for food resulting from the low purchasing power of the population (Cherevko, 2017; Grużewska et al., 2017). This affects not only the volume of production, but also its structure, because the demand for more expensive animal products is limited, and the development of such production is difficult (Cherevko, 2017). Still, part of the population consumes too little protein from animal products due to their high prices (Nemchenko, 2013; Nemchenko, 2013). Significant disturbances in the development of agriculture also appeared in connection with the financial crisis within the period 2007-2009 and the decline in the export of agricultural products and their prices (Dibrova, Dibrova, 2009; Grużewska et al., 2017).

Support for agricultural development from the Ukrainian state is considered too low, which results from budgetary constraints, but is often not properly targeted, therefore is not enough to modernize agriculture (Dibrova et al., 2015; Dibrova, Chan-khi, 2013). It is believed that without institutional support under the programs for agricultural development it will be difficult to obtain the expected increase in agricultural production (Malik and Zaburanna, 2014). Support programs should be aimed at supporting those agricultural sectors that are the most delayed in development (Mazur and Pimenova, 2014) and mainly concern the introduction of modern production techniques (Dibrova et al., 2011). The importance of technical progress in the growth of agricultural productivity is now higher than the importance of increasing land inputs or industrial production resources, which is observed in countries at every level of economic development (Wicki, 2016). Due to different needs emerging in particular regions of the country, agricultural development programs must also be regionally differentiated (Chemerys and Krupin, 2015), taking into account the needs of medium and small farms (Melnyk, 2013; Orlykovskyi, Wicki, 2016) and support sustainable rural development (Moroz, 2012).

Very good production conditions as well as access to large land resources in organized units favored the emergence of very large enterprises dealing in agriculture and the appearance of foreign investments in agricultural farms (Heyenko, 2010). Many large, vertically integrated agricultural holdings were established, which raise capital even on foreign stock exchanges, also in Warsaw (Cherevko, 2012; Melnyk, 2013). The 
development of agroholdings leads to an increase in the scope of food processing and export from Ukraine.

Agriculture in Ukraine has a stable share in generating GDP and in exports (Cherevko, 2015). The opening of foreign markets, including EU markets, to agricultural products from Ukraine enables further development of production, especially when not only exports of raw materials, but also exports of more processed products would take place (Dibrova et al., 2014; Bukin et al., 2015). In the structure of value-added production in agribusiness, agriculture should take the second place after food processing. This result was achieved in Poland twenty years after the transformation (Wicki and Grontkowska 2015). Another direction of development may be an increase in biomass consumption for biofuels (Galchynska et al., 2015). According to some authors, the production of rape for transport biofuels is profitable under Ukrainian farming conditions and can be implemented on a large scale (Cherevko, 2016; Zaika et al., 2014). However, such production competes with food production (Wicki, 2017), and is also heavily exposed to production and market risks (Wicka, 2013).

According to the energy balance, in 2013, the share of energy produced from biomass in Ukraine did not exceed $2 \%$. Potentially as much as $18 \%$ of the total primary energy consumption can be generated there from the available biomass. Presently for the production of electricity in Ukraine, wood chips and sunflower husks are used the most. The use of wood biomass potential reaches $80 \%$, whereas of husks $-59 \%$. Therefore, it is required to concentrate on technologies, which can be cost competitive, such as biomass in by-products, energy and biogas produced from waste. Unfortunately, with low world fuel prices, the production of energy from biomass is usually unprofitable.

Agriculture in Ukraine has many strengths. These are: high quality of soils, large land resources, the possibility of obtaining surplus production in relation to domestic demand, as well as low production costs. However, the financing of agricultural development is still a problem that needs to be solved. In Ukraine there is too little capital for financing the developmental needs of agriculture due to many other, competitive applications (Vaschyk, 2012). Agricultural farms are increasingly using bank loans in financing development (Adamenko et al., 2015), but for smaller entities, access to loans is difficult (Borisova, 2009), and some managers, fearing the risk, prefer to use safer, internal financing sources (Zabolotnyy, 2016). The economic crisis observed in recent years leads to further limitation of the financing development possibilities.

In view of the many challenges faced by Ukrainian agriculture, similar to those observed in Poland since the mid-1990s, it seems reasonable to make a comparative analysis of the development trends of Polish and Ukrainian agriculture.

\section{Aim and methodological assumptions}

The aim of this study is a comparative assessment of development trends in agriculture in Poland and Ukraine, establishing development similarities and presenting perspectives for further agricultural development in Ukraine.

The study includes a critical analysis of the literature, which was used as the basis for determining the direction of further research. In the next stage statistical data presented by the FAO were used in order to make a comparative analysis of Polish and Ukrainian agriculture. This data source was chosen because of the possibility of obtaining comparable 
data for longer periods. The analysis covered the years 1995-2014. The data was compiled in the form of time series and the differences in the dynamics and level of presented phenomena were assessed. A time gap in achieving productivity gains was also identified.

The comparison of Polish and Ukrainian agriculture was made in the area of overall efficiency of production factors, size and efficiency of plant and animal production as well as the size and dynamics of foreign trade in agro-food products.

\section{Resources of production factors in agriculture and their productivity}

Comparison of changes in agriculture in Poland and Ukraine is justified because in the 1990s, both countries transformed the system and reformed the economy. There are significant developmental analogies, including a decline in agricultural production during the restructuring period and its development in subsequent years. The observed development gap is the basis for determining the analogy in changes occurring in agriculture. It is also possible to define medium-term prospects for using the potential of agriculture in Ukraine, taking into account the dynamics and level of productivity achieved in Poland.

Agriculture in the analysed countries has a different role in the economy. In Poland after the political transformation in the $90 \mathrm{~s}$ of the 20th century, the importance of agriculture decreased from almost $10 \%$ to $5 \%$ of GDP. After 2000, the share of agriculture in the economy did not exceed 3\% and remained at this level. In the Ukrainian economy, agriculture plays a greater role. By 2004, it was $10-14 \%$ of GDP, and in subsequent years it did not fall below 6\% (fig. 1).

In Ukraine, the production potential of agriculture is very high, mainly due to the large agricultural land resources and a significant share of soils with high usefulness for agricultural production. The total area of the country is 603 thousand $\mathrm{km}^{2}$, and the area of agricultural land is 41.3 million ha, of which arable land is 32.5 million ha. It is more than twice as much as in Poland, where the area of agricultural land does not exceed 15 million ha, and the arable land area is around 11 million ha (fig. 2).

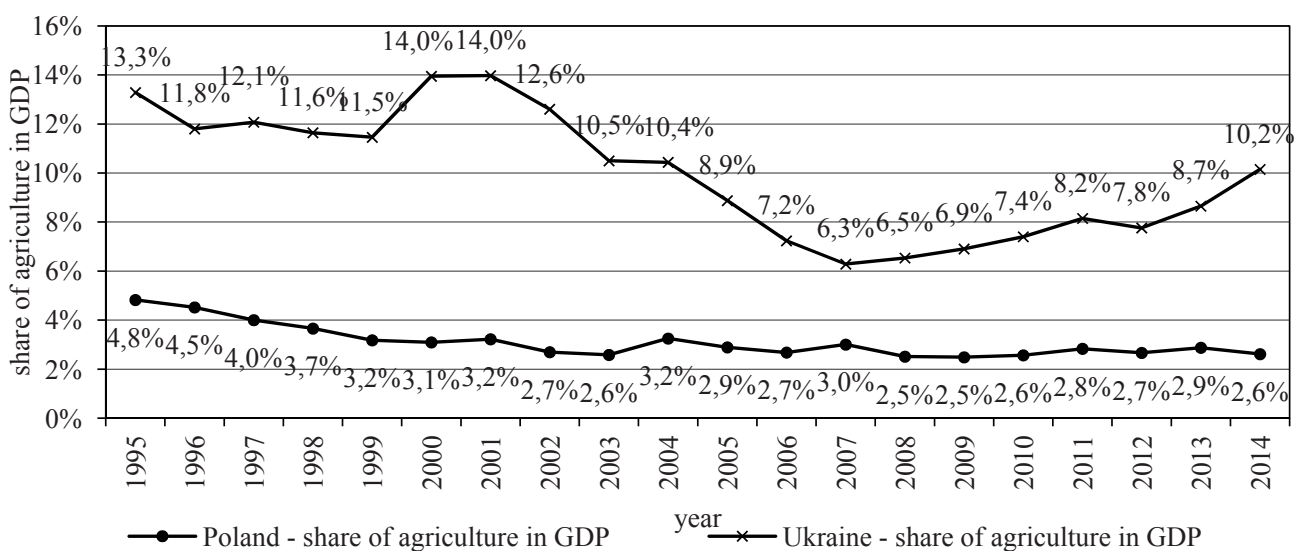

Fig. 1. Share of agriculture in GDP in Poland and Ukraine in period 1995-2014

Source: own elaboration based on FAO data. 


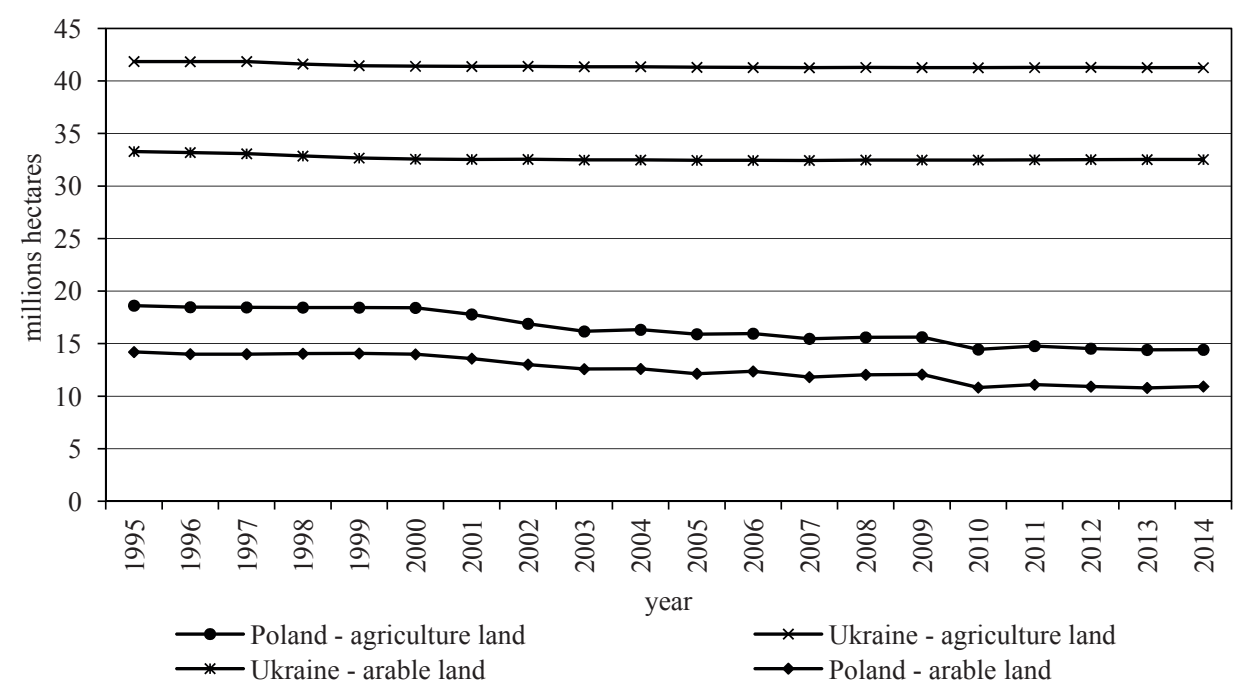

Fig. 2. Area of agriculture land in Poland and Ukraine (million hectares)

Source: own elaboration based on FAO data.

About 2 million people work in agriculture in Poland. There is a visible downward trend. In Ukraine, it is estimated that about 3 million people work in agriculture, but they are both people working on large farms and on family farms (fig. 3). It should be noted that the data presented by the FAO differ from the data provided in other statistical data for Ukraine, in which the number of 3.1 million employed in agriculture was presented (Orlykovskyi et al., 2016), which results from a different inclusion of wage workers in statistics. The level of employment in agriculture in Poland varied from around 18 people per 100 ha of agricultural land in 1995 to 13 people per 100 ha in 2014 . In Ukraine, in the same period there was a reduction in the employment rate from 12.7 to 9.9 people per 100 ha of agricultural land. Significant differences occur in the structure of farms. There are about 53,000 agricultural enterprises in Ukraine with various ownership forms, of which around $74 \%$ are farms, but the number of large agroholdings is also significant, especially in land use. Agriculture in Poland is very fragmented, in 2015 there were about 1.3 million farms with an average area of just 10 ha. This means that Ukrainian agriculture has much greater opportunities in agricultural production, and thus it can be much more competitive, especially on international markets. In the whole agribusiness, a similar percentage of employees in both compared countries is employed. It is about $17 \%$ of employees (Wicki, Grontkowska, 2015). 


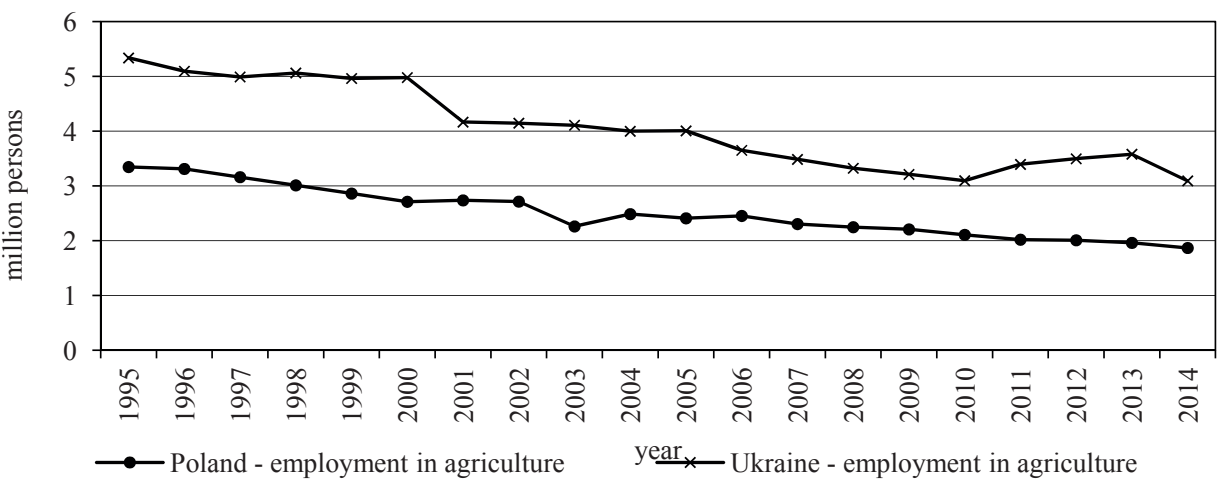

Fig. 3. Employment in Polish and Ukrainian agriculture in period 1995-2014 in million persons Source: own elaboration based on FAO data.

Since 2000, the total value of production in Ukrainian agriculture is higher than in Poland. In addition, a steady upward trend can be noted, while in Poland there is no visible increase in production. In 2000, the volume of agricultural production was comparable, and in 2014, agricultural production in Ukraine was already $60 \%$ higher than the value of agricultural production in Poland. With a large difference in the resources of production factors, the differences in the volume of production in the compared countries are not large. Figure 4 and Table 1 present a comparison of the value of agricultural production in Poland and Ukraine. The value of production in Poland is much higher per 1 ha of agricultural land and per one worker in agriculture due to the higher production efficiency in some sectors, but also due to the different production structure. In Poland, higher processed animal production, reaching higher prices, accounts for about $60 \%$ of agricultural production, and in Ukraine it is about $30 \%$. The increase in the value of production can therefore be obtained by supplying higher-processed agricultural products. This is discouraged by high productivity in crop production, which is relatively easy to obtain on good soils in Ukraine. This means that the potential of agriculture in Ukraine is still not fully exploited.

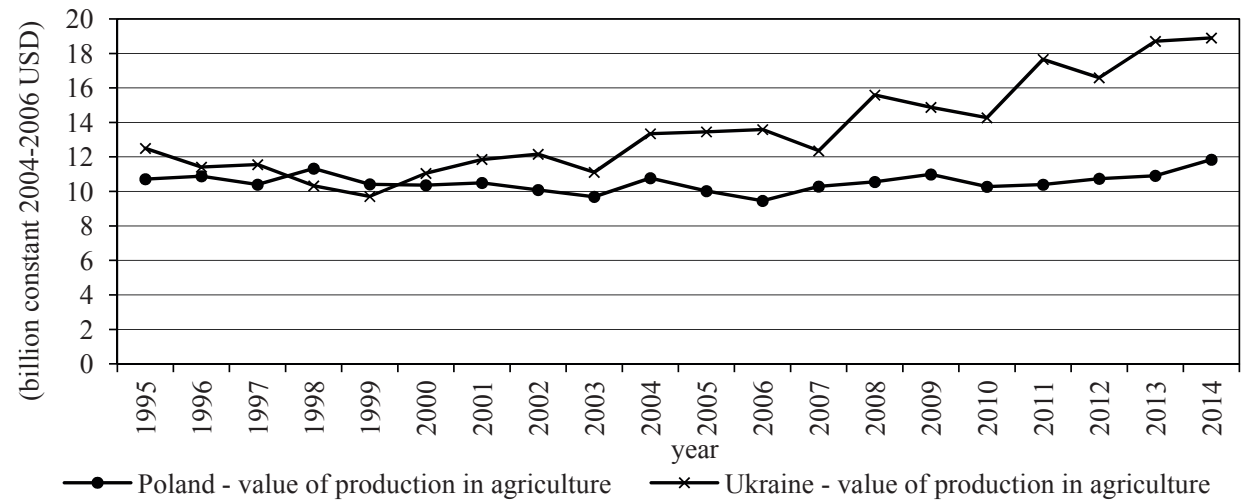

Fig. 4. Value of agriculture production in Poland and Ukraine in period 1995-2014

Source: own elaboration based on FAO data. 
Taking into account the productivity of labour and land, it is worth noting that the growth rate of productivity in Ukrainian agriculture was much higher than that observed in Poland (tab. 1).

Table 1. Labor and agriculture land productivity in Poland and Ukraine (constant 2004-2006 USD)

\begin{tabular}{|c|c|c|c|c|}
\hline \multirow{2}{*}{ Year } & \multicolumn{2}{|c|}{$\begin{array}{l}\text { Labor productivity per worker in } \\
\text { thousand constant 2004-2006 USD }\end{array}$} & \multicolumn{2}{|c|}{$\begin{array}{l}\text { Agriculture land productivity per } 1 \text { ha } \\
\text { in constant 2004-2006 USD }\end{array}$} \\
\hline & Poland & Ukraine & Poland & Ukraine \\
\hline 1995 & 3204 & 2343 & 575 & 299 \\
\hline 1996 & 3289 & 2241 & 589 & 273 \\
\hline 1997 & 3291 & 2318 & 563 & 276 \\
\hline 1998 & 3763 & 2041 & 614 & 248 \\
\hline 1999 & 3642 & 1957 & 565 & 234 \\
\hline 2000 & 3823 & 2221 & 563 & 267 \\
\hline 2001 & 3837 & 2846 & 590 & 286 \\
\hline 2002 & 3718 & 2934 & 597 & 294 \\
\hline 2003 & 3900 & 2705 & 599 & 269 \\
\hline 2004 & 4473 & 3339 & 660 & 323 \\
\hline 2005 & 4088 & 3360 & 630 & 326 \\
\hline 2006 & 4105 & 3725 & 593 & 329 \\
\hline 2007 & 4579 & 3547 & 665 & 299 \\
\hline 2008 & 4784 & 4694 & 677 & 378 \\
\hline 2009 & 5216 & 4634 & 704 & 361 \\
\hline 2010 & 5091 & 4612 & 711 & 346 \\
\hline 2011 & 5177 & 5204 & 703 & 428 \\
\hline 2012 & 5480 & 4745 & 739 & 402 \\
\hline 2013 & 5845 & 5230 & 757 & 453 \\
\hline 2014 & 6510 & 6113 & 821 & 458 \\
\hline $\begin{array}{l}\text { Change }(1995-1999 / 2010- \\
2014),(1995-1999=100)\end{array}$ & 163 & 238 & 128 & 157 \\
\hline CAGR (\%) & 3.3 & 5.8 & 1.7 & 2.9 \\
\hline
\end{tabular}

Source: own elaboration based on FAO and State Statistics Service of Ukraine data.

Labour productivity in Ukrainian agriculture grew at a rate of $5.8 \%$ per annum, and in Poland it was only $3.3 \%$ per annum. It should be emphasized that labour productivity in agriculture in Poland is still significantly lower than that observed in more developed EU countries (Wicki 2012). Similar differences were observed in the rate of increase in land productivity. In Polish agriculture, an average annual growth of $1.7 \%$ was observed in the analysed period, and in Ukraine it was $2.9 \%$ per annum. 


\section{The amount and efficiency of production in agriculture}

The amount of agricultural production depends both on the sown area of individual plants and the number of animals, as well as on productivity. While the production area is stable under normal conditions, performance changes can have a significant effect on production. Table 2 shows the production area and population of selected groups of plants and animals. The size of production in Ukrainian agriculture is much higher than in Poland. The decrease in cereal and potato production and the increase in the production area of oilseeds is evident in both countries. It is also worth noting the strong growth of poultry production in Ukraine with a strong, over $30 \%$ decline in cattle and pigs. In Poland, changes in production volumes were much lower, which proves a more stable situation in agriculture and its environment.

Table 2. Area of main crops and livestock population in Poland and Ukraine

\begin{tabular}{|c|c|c|c|c|c|c|c|c|c|c|c|c|c|c|c|c|}
\hline \multirow[b]{2}{*}{ Year } & \multicolumn{2}{|c|}{ Cereals } & \multicolumn{2}{|c|}{ Potato } & \multicolumn{2}{|c|}{ Sugar beet } & \multicolumn{2}{|c|}{ Rape } & \multicolumn{2}{|c|}{ Sunflower } & \multicolumn{2}{|c|}{ Cattle } & \multicolumn{2}{|c|}{ Poultry } & \multicolumn{2}{|c|}{ Pigs } \\
\hline & PL & UA & PL & $\begin{array}{l}\text { UA } \\
\qquad \text { in m }\end{array}$ & PL & UA & PL & UA & PL & UA & PL & $\begin{array}{l}\text { UA } \\
\quad \text { in }\end{array}$ & $\begin{array}{l}\text { PL } \\
\text { millio }\end{array}$ & $\begin{array}{l}\text { UA } \\
\text { on heads }\end{array}$ & PL & UA \\
\hline 1995 & 8.6 & 12.9 & 1.5 & 1.5 & 0.4 & 1.4 & 0.6 & 0.0 & 0.0 & 2.0 & 7.3 & 20.4 & 53.6 & 157.0 & 20.4 & 13.9 \\
\hline 1996 & 8.7 & 11.7 & 1.3 & & 0.5 & 1.3 & 0.3 & & & 2.0 & 7.1 & 18.0 & 51.7 & 143.0 & 18.0 & 13.1 \\
\hline 1997 & 8.9 & 13.8 & 1.3 & 1.6 & 0.4 & 1.0 & 0.3 & & 0.0 & 2.0 & 7.3 & 18.1 & 56.3 & 145.0 & 18.1 & 11.2 \\
\hline 1998 & 8.8 & 12.2 & 1.3 & 1.5 & 0.4 & 0.9 & 0.5 & 0.1 & 0.0 & 2.4 & 7.0 & 19.2 & 54.7 & 138.0 & 19.2 & 9.5 \\
\hline 1999 & 8.7 & 12.0 & 1.3 & 1.6 & 0.4 & 0.9 & 0.5 & 0.2 & 0.0 & 2.8 & 6.6 & 18.5 & 54.3 & 129.0 & 18.5 & 10.1 \\
\hline 2000 & 8.8 & 12.2 & 1.3 & 1.6 & 0.3 & 0.7 & 0.4 & 0.2 & 0.0 & 2.8 & 6.1 & 17.1 & 54.6 & 139.0 & 17.1 & 10.1 \\
\hline 2001 & 8.8 & 14.3 & 1.2 & 1.6 & 0.3 & 0.9 & & 0.1 & 0.0 & 2.4 & 5.7 & 17.1 & 53.3 & 123.7 & 17.1 & 7.7 \\
\hline 2002 & 8.3 & 13.8 & 0.8 & 1.6 & 0.3 & 0.8 & 0.4 & 0.1 & 0.0 & 2.7 & 5.5 & 18.7 & 55.6 & 136.8 & 18.7 & 8.4 \\
\hline 2003 & 8.2 & 10.6 & 0.8 & 1.6 & 0.3 & 0.7 & 0.4 & 0.1 & 0.0 & 3.8 & 5.5 & 18.6 & 173.9 & 146.9 & 18.6 & 9.2 \\
\hline 2004 & 8.4 & 14.4 & 0.7 & 1.6 & 0.3 & 0.7 & 0.5 & 0.1 & 0.0 & 3.4 & 5.4 & 17.0 & 167.6 & 141.9 & 17.0 & 7.3 \\
\hline 2005 & 8.3 & 14.2 & 0.6 & 1.5 & 0.3 & 0.6 & 0.6 & 0.2 & 0.0 & 3.7 & 5.5 & 18.1 & 152.8 & 152.1 & 18.1 & 6.5 \\
\hline 2006 & 8.4 & 13.8 & 0.6 & 1.5 & 0.3 & 0.8 & 0.6 & 0.4 & 0.0 & 3.9 & 5.6 & 18.9 & 141.6 & 161.5 & 18.9 & 7.1 \\
\hline 2007 & 8.4 & 13.1 & 0.5 & 1.5 & 0.2 & 0.6 & 0.8 & 0.8 & 0.0 & 3.4 & 5.7 & 18.1 & 150.5 & 166.2 & 18.1 & 8.1 \\
\hline 2008 & 8.6 & 15.1 & 0.5 & 1.4 & 0.2 & 0.4 & & 1.4 & 0.0 & 4.3 & 5.8 & 15.4 & & 168.8 & 15.4 & 7.0 \\
\hline 2009 & 8.5 & 15.1 & 0.5 & 1.4 & 0.2 & 0.3 & & 1.0 & 0.0 & 4.2 & 5.7 & 14.3 & 140.6 & 176.5 & 14.3 & 6.5 \\
\hline 2010 & 7.9 & 14.2 & 0.5 & 1.4 & 0.2 & 0.5 & 0.9 & 0.9 & 0.0 & 4.5 & 5.7 & 14.9 & 131. & 190.1 & 14.9 & 7.6 \\
\hline 2011 & 7.7 & 15.0 & 0.4 & 1.4 & 0.2 & 0.5 & 0.8 & 0.8 & 0.0 & 4.7 & 5.8 & 13.5 & 113 & 202.5 & 13.5 & 8.0 \\
\hline 2012 & 7.6 & 14.5 & 0.4 & 1.4 & 0.2 & 0.4 & 0.7 & 0.5 & 0.0 & 5.1 & 5.8 & 11.6 & 1300 & 199.8 & 11.6 & 7.4 \\
\hline 2013 & 7.5 & 15.5 & 0.3 & 1.4 & 0.2 & 0.3 & 0.9 & 1.0 & 0.0 & 5.1 & 5.9 & 11.2 & 1404 & 213.2 & 11.2 & 7.6 \\
\hline 2014 & 7.5 & 14.4 & 0.3 & 1.3 & 0.2 & 0.3 & 1.0 & 0.9 & 0.0 & 5.2 & 5.9 & 11.7 & 146.6 & 229.0 & 11.7 & 7.9 \\
\hline Change* & 87 & 118 & 28 & 91 & 48 & 36 & 197 & 1017 & - & 219 & 82 & 67 & - & 145 & 67 & 66 \\
\hline CAGR (\%) & -0.8 & 1.1 & -8.7 & -0.8 & -4.7 & -7.1 & 5.1 & 19.2 & - & 5.3 & -1.1 & -2.6 & - & 2.5 & -2.5 & -2.8 \\
\hline
\end{tabular}

* - change between 1995-1999 and 2010-2014, (1995-2000=100), "_" no data or indicator cannot be calculated because of differences in time data collection method

Source: own elaboration based on FAO and State Statistics Service of Ukraine data. 
In the analysed period, an increase in productivity in plant and animal production was observed in both countries. The level of productivity in Poland is still higher than in Ukraine, despite the average worse conditions for production, but yields have already been obtained in the production of cereals and rape (tab. 3). The dynamics of cereal yield increase in Poland amounted to $1.6 \%$ per year, and in Ukraine 3.2\% per year. Similar growth dynamics was obtained for other plant species and in the case of milk yield of cows (fig. 5). Productivity in Ukrainian agriculture grew much faster than Polish. This is another proof of the high potential of Ukrainian agriculture, which has not been and is still not fully used.

Table 3. Yields in agriculture in Poland and Ukraine

\begin{tabular}{|c|c|c|c|c|}
\hline \multirow[b]{2}{*}{ Item } & \multicolumn{2}{|c|}{ Poland } & \multicolumn{2}{|c|}{ Ukraine } \\
\hline & $\begin{array}{l}\text { average in } \\
1995-1999\end{array}$ & $\begin{array}{l}\text { average in } \\
2010-2014\end{array}$ & $\begin{array}{l}\text { average in } \\
1995-1999\end{array}$ & $\begin{array}{l}\text { average in } \\
2010-2014\end{array}$ \\
\hline Cereals (dt/ha) & 30 & 37 & 22 & 36 \\
\hline Potato (dt/ha) & 177 & 223 & 101 & 160 \\
\hline Sugar beet (dt/ha) & 367 & 580 & 179 & 386 \\
\hline Rape (dt/ha) & 20 & 27 & 9 & 21 \\
\hline Milk yield per cow (litres) & 3594 & 5211 & 2186 & 4315 \\
\hline
\end{tabular}

Source: own elaboration based on FAO data.

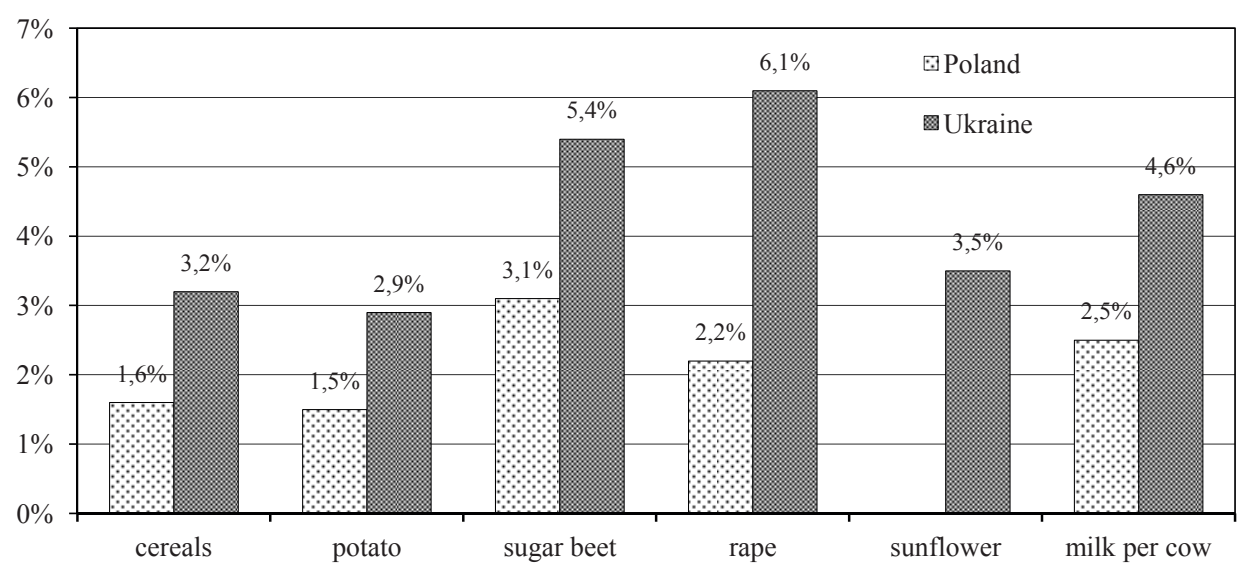

Fig. 5. Average annual growth rate of yields in Polish and Ukrainian agriculture in period 1995-2014

Source: own elaboration based on FAO data.

Changes in the area of plant cultivation and animal population as well as the increase in unit productivity result in changes in the production volume. Despite increasing productivity, production of some agricultural raw materials decreased. Cereal and oil crops increased and production of potatoes and sugar beet decreased. A significant increase was observed in cereal production in Ukraine, which almost doubled from 30 to over 60 million tonnes per year. In Poland, cereal crops increased by $10 \%$. Beet harvest decreased by over $20 \%$, rapeseed harvest increased significantly. $\mathrm{n}$ Poland, it was a $150 \%$ increase and in 
Ukraine it was multiple (tab. 4). In animal production, the changes were slightly smaller. Milk production in Ukraine even decreased, and in the production of meat there was a change in the internal structure of production - pork production decreased and poultry production increased. It is worth noting that in the analysed period there was no increase in animal production in Ukraine, with the exception of poultry production, which developed in large industrial farms. Production of cereals, potatoes and oil increased in crop production. No such large changes were observed in Poland, but the production of oilseeds and poultry meat increased. It can be assumed that with the development of agriculture in Ukraine, animal production will be increased, which can be done based on feed from domestic production.

Table 4. Changes in production of main agricultural commodities in Poland and Ukraine (million tons)

\begin{tabular}{|c|c|c|c|c|}
\hline \multirow{3}{*}{ Commodity } & \multicolumn{2}{|c|}{ Poland } & \multicolumn{2}{|c|}{ Ukraine } \\
\hline & $\begin{array}{c}\text { average in } 1995- \\
1999\end{array}$ & $\begin{array}{l}\text { average in 2010- } \\
2014\end{array}$ & $\begin{array}{c}\text { average in } 1995- \\
1999\end{array}$ & $\begin{array}{l}\text { average in 2010- } \\
2014\end{array}$ \\
\hline & \multicolumn{4}{|c|}{ milion tons } \\
\hline Cereals & 25.9 & 28.4 & 28.0 & 53.3 \\
\hline Potato & 23.8 & 8.2 & 15.6 & 22.4 \\
\hline Sugar beet & 15.0 & 11.7 & 20.0 & 15.5 \\
\hline Rape & 0.9 & 2.4 & 0.1 & 1.7 \\
\hline Sunflower & - & - & 2.5 & 9.0 \\
\hline Beef & 0.4 & 0.4 & 0.9 & 0.4 \\
\hline Pork & 2.0 & 1.9 & 0.7 & 0.7 \\
\hline Poultry & 0.5 & 1.5 & 0.2 & 1.1 \\
\hline Milk & 12.1 & 12.6 & 14.6 & 11.0 \\
\hline
\end{tabular}

Source: own elaboration based on FAO data.

\section{Foreign trade in food products}

The products of agriculture and the food industry constitute a significant share in the foreign trade turnover both in Poland and in Ukraine. Exports of grocery products from Poland reached about USD 26 billion, and the positive balance amounted to about USD 8 billion (fig. 6). The share of agricultural and grocery products in exports in recent years amounted to $11-13 \%$. Exports of agricultural and food products from Ukraine was increasing and reached USD 17 billion, with imports of around USD 7 billion. The positive trade balance in agricultural products was therefore even USD 10 billion. Export of agricultural products from Ukraine constitutes up to $40 \%$ of the total export. Cereals and vegetable oils have the largest share - as much as $65 \%$. With the development of agri-food processing, it will be possible to increase the share of highly processed products in exports and increase its profitability.

Considering the importance of exporting agri-food products in Ukraine's exports, it should be noted that it is much higher than the share of agribusiness in the economy, which is ca. $16 \%$, and also higher than the share of employment in this sector $(17 \%)$. The value of 
Ukrainian foreign trade in agri-food products may grow with the further development of agriculture and agribusiness in this country unless new trade barriers emerge. The increase in the share of agri-food products in foreign trade turnover has not been recorded since 2013 despite the increase in turnover in nominal terms. Considering the stable level of production in agriculture, it can be assumed that there will be no further increase in the importance of agribusiness in Polish foreign trade. In Ukraine, the level of saturation in the development of foreign trade in agri-food products has not yet been achieved.

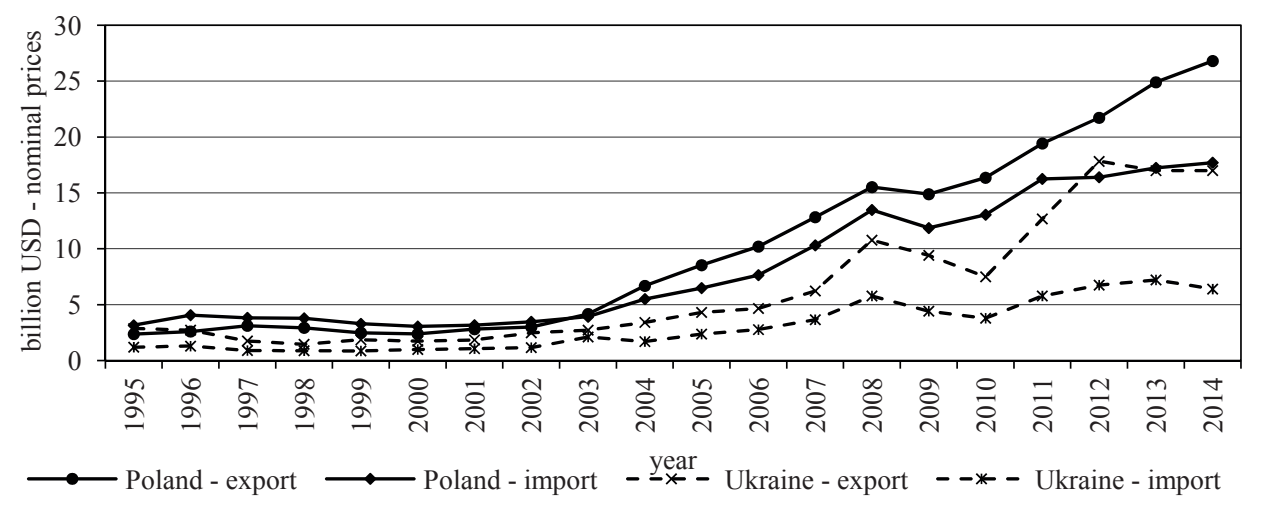

Fig. 6. Foreign trade in agri-food products in Poland and Ukraine in period 1995-2014

Source: own elaboration based on FAO data.

\section{Conclusions}

1. Agriculture in Ukraine has a high share in the creation of gross domestic product. Its development may contribute to the development of the entire economy and to achieving a higher standard of living. There are significant limitations in this respect. The most important ones include: lack of regulation of land ownership, limited access to capital for agricultural development, as well as insufficient preparation of domestic programs for the development of agriculture and rural areas. Strengths include high land provision, the opportunity to obtain surplus food relative to domestic consumption, as well as low production costs.

2. An important factor for the growth of the agribusiness sector is the legislative and financial support for the development of the agricultural environment, such as production and distribution infrastructure. At present, only large agro-holdings have a sufficiently vertically integrated system covering production, processing and distribution. Farms need support to develop this type of integration on an arm's length basis.

3. In Ukrainian agriculture, similar productivity was achieved as in Polish agriculture, but land productivity is twice lower there. An opportunity for further, rapid increase in labour productivity is a high concentration of land in farms in Ukraine, and for increasing land productivity - an increase in production intensity. 
4. In the years 1995-2014, an increase in productivity in plant and animal production was observed in Ukraine. The development gap in this respect in relation to Polish agriculture concerns the production of rapeseed, sugar beet, potatoes and milk production. The time gap is about 10 years.

5. In Ukrainian agriculture, there was a faster growth in crop production than in Poland. This resulted both from the lower reference base and the greater potential associated with good natural conditions for production development. It should be assumed that in the Ukrainian agriculture it is possible to obtain higher yield in crop production than in Poland in the perspective of $10-15$ years.

6. The production of basic agricultural raw materials in Ukraine: cereals and oilseeds, exceeds domestic demand. This is the basis for the development of export of agricultural products. The share of agricultural exports in total Ukrainian exports is as much as $40 \%$. There is also a USD 10 billion trade surplus observed. With the development of animal production, the profitability of production exports may increase.

7. Ukraine is a major producer and exporter of agri-food products in the world and can benefit from favourable natural conditions to increase the production of grocery raw materials, food with high added value. There is a rapid increase in productivity and production in agriculture. In the period of 10-15 years, it is possible to achieve the level of efficiency observed in other countries of Central and Eastern Europe.

8. The success in further development of agribusiness in Ukraine depends to a large extent on the introduction of nationwide programs for the development and support of agriculture and rural areas. The unstable economic and political situation in Ukraine observed for several years and the related deficiencies in making pro-development regulations and in accessing capital is one of the main factors limiting the development of the sector.

\section{References}

Adamenko, V., Oliynyk, O., Wasilewski, M. (2015). Financial System and Agricultural Growth: Evidence from Poland and Ukraine. Scientific Journal Warsaw University of Life Sciences SGGW Problems of World Agriculture, 15(4), 204-214.

Borisova, V. (2009). Dostep do pożyczek spółdzielni rolniczych na Ukrainie. Zeszyty Naukowe SGGW Ekonomika i Organizacja Gospodarki Żywnościowej, 77, 41-52.

Bukin, E., Skrypnyk, A., Talavyria, M. (2015). Wzrost gospodarek wchodzących: w kierunku rynków rolnych i stosunków handlowych. Niestabilność światowego rynku pszenicy na rynkach wschodzących. Zarzadzanie Finansami i Rachunkowość, 1, 47-62.

Chemerys, V., Krupin, V. (2015). Economic zoning as the basis for development of infrastructural support for regional agricultural markets in Ukraine: theoretical approach. JARD, 4(38), 627-634.

Cherevko, G. (2012). Agricultural Holding as new organizational form of multiple issues manage in the agribusiness of Ukraine, Agrarian Economy, 5(1-2), 32.

Cherevko, G. (2015). Efektywność funkcjonowania gospodarki żywnościowej na Ukrainie. Roczniki Naukowe SERiA, 17(4), 70-74.

Cherevko, G. (2016). Rapeseed growing for energy purposes in Ukraine. Roczniki Naukowe SERiA, 18(3), 29-34.

Cherevko, G. (2017). Food safety in Ukraine and its factors. Roczniki Naukowe SERiA, 19(3), 29-33.

Dibrova, A., Chan-khi, O. (2013). Policy Analysis Matrix: An Analysis of the Effectiveness of State Agricultural Policy for the Dairy Sector in Ukraine. Scientific Journal Warsaw University of Life Sciences SGGW Problems of World Agriculture, 13(4), 18-24.

Dibrova, A., Dibrova, L. (2009). Domestic support for Ukrainian agriculture under the conditions of world financial crisis. Scientific Journal Warsaw University of Life Sciences SGGW Problems of World Agriculture, 6, 26-32. 
Dibrova, A., Dibrova, L., Krylov, Y. (2011). Domestic Support of Livestock Production in Ukraine. Zeszyty Naukowe SGGW Problemy Rolnictwa Światowego, 11(1), 54-62.

Dibrova, A., Dibrova, L., Labenko, O. (2015). State Financial Support of Agriculture in Ukraine. Scientific Journal Warsaw University of Life Sciences SGGW Problems of World Agriculture, 15(4), 26-32.

Dibrova, A., Dibrova, L., Ryabchenko, O., Zhemoyda, O. (2014). Ukrainian Prospects in the Space of European Agro-food Trade Based on Quantitative Economic Analysis. Scientific Journal Warsaw University of Life Sciences SGGW Problems of World Agriculture, 14(4), 57-71.

Galchynska, J., Maciejczak, M., Orlykovskyi, M. (2015). Development of Bioenergy from Biomass in Ukraine. Scientific Journal Warsaw University of Life Sciences SGGW Problems of World Agriculture, 15(4), 56-61.

Gołębiewska, B. (2011). Significance of Connections with the Environment of Agricultural Farms in Poland for Their Production and Economic Situation. Economic Science for Rural Development, 24, 40-49.

Grużewska, A., Gugała, M., Yatsyshyn, A., Zarzeczna, K. (2017). Produkcja i jakość ziemniaka jadalnego w opinii konsumentów w Polsce i na Ukrainie. Zeszyty Naukowe SGGW Problemy Rolnictwa Światowego, 17(3), 308-318.

Heyenko, M. (2010). Zagraniczne inwestowanie w rozwój przedsiębiorstw rolniczych. Zeszyty Naukowe SGGW Ekonomika i Organizacja Gospodarki Żywnościowej, 81, 53-62.

Malik, M., Zaburanna, L. (2014). Mechanizm interwencji państwa na rzecz rozwoju sfery agrarnej gospodarki Ukrainy. Zarzqdzanie Finansami i Rachunkowość, 1, 59-67.

Mazur, I., Pimenova, O. (2014) Priorytety wsparcia instytucjonalnego nowoczesnych form działalności w systemie agrarnym Ukrainy. Zarzqdzanie Finansami i Rachunkowość, 1, 69-77.

Melnyk, K. (2013). The Peculiarities of Formation and Development of Agricultural Holdings in Ukraine. Scientific Journal Warsaw University of Life Sciences SGGW Problems of World Agriculture, 13(4), 122-130.

Moroz, S. (2012) Structural Changes in Agriculture of Ukraine: Results and Perspectives. Scientific Journal Warsaw University of Life Sciences SGGW Problems of World Agriculture, 12(3), 81-92.

Nemchenko, H. (2013). Modern approaches to food security of Ukraine. Proceedings of Kirovograd National Technical University. Economics, 23, 401-406.

Nemchenko, V. (2013). Food security: macro and micro aspects. Economics of Food Industry, 2, 16-18.

Orlykovskyi, M. Wicki, L., Maciejczak, M., Galchynska, Y. (2016). Rozwój biogospodarki opartej na wiedzy na Ukrainie - w kierunku systemu dyfuzji innowacji opartego o model poczwórnej helisy. Zeszyty Naukowe SGGW Problemy Rolnictwa Światowego, 16(1), 164-176.

Orlykovskyi, M., Wicki, L. (2016). Polityka i programy wsparcia rolnictwa w warunkach stowarzyszenia i członkostwa Polski w Unii Europejskiej. Wnioski dla Ukrainy. Wydawnictwo SGGW: Warszawa.

Vashchyk, M. (2012). Partnerstwo publiczno-prywatne jako czynnik zapewniający zrównoważony rozwój agrobiznesu na Ukrainie. Roczniki Ekonomii Rolnictwa i Rozwoju Obszarów Wiejskich, 99(3), 93-99.

Wicka, A. (ed.) (2013). Czynniki i możliwości ograniczania ryzyka w produkcji roślinnej poprzez ubezpieczenia. Wydawnictwo SGGW: Warszawa.

Wicka, A., Wicki, L. (2016). Bio-Economy Sector in Poland and Its Importance in the Economy. Economic Science for Rural Development, 41, 219-228.

Wicki, L. (2012). Convergence of Labour Productivity in Agriculture in the European Union. Economic Science for Rural Development, 27, 279-284.

Wicki, L. (2016). Zmiany produktywności czynników wytwórczych w polskim rolnictwie. Zeszyty Naukowe SGGW Ekonomika i Organizacja Gospodarki Żywnościowej, 116, 149-160.

Wicki, L., (2017). Food and Bioenergy - Evidence from Poland. Economic Science for Rural Development, 44, $299-305$.

Wicki, L., Grontkowska, A. (2015). Zmiany znaczenia agrobiznesu w gospodarce i w jego wewnętrznej strukturze. Roczniki Naukowe Ekonomii Rolnictwa i Rozwoju Obszarów Wiejskich, 102(3), $20-32$.

Zabolotnyy, S. (2016). Principles of financial management in Ukrainian agribusiness companies. Zarzqdzanie Finansami i Rachunkowość, 4, 63-75.

Zaika, S., Chibowski, P., Izdebski, W., Krygul, R., Makarchuk, O., Skudlarski, J., Zając, S. (2017). Przemiany w wyposażeniu technicznym gospodarstw rolnych na Ukrainie w latach 2000-2015. Zeszyty Naukowe SGGW Problemy Rolnictwa Światowego, 17(1), 182-194.

Zaika, S., Maznev, G., Izdebski, W., Jakubowski, Z., Skudlarski, J., Zając, S. (2014). Stan i perspektywy produkcji rzepaku w Polsce i na Ukrainie w aspekcie produkcji biopaliw transportowych. Zeszyty Naukowe SGGW Problemy Rolnictwa Światowego, 14(2), 80-89. 